\title{
Assessment of left ventricular volumes; reliable by gated SPECT?
}

\author{
E. E. van derWall • A. J. H. A. Scholte • \\ H. M. Siebelink • J. J. Bax
}

Received: 17 September 2010/ Accepted: 23 September 2010/Published online: 6 October 2010

(C) The Author(s) 2010. This article is published with open access at Springerlink.com

Assessment of cardiac function continues to be an important issue in patients with assumed left ventricular dysfunction [1-10]. In particular in patients with enlarged left ventricles, such as occurs in ischemic and idiopathic dilated cardiomyopathy, accurate assessment of left ventricular function remains pivotal [11-14]. To assess myocardial function, different diagnostic methods are currently performed, such as MRI, SPECT, and echocardiography [15-23]. In the clinical arena, detection of myocardial function is predominantly based on echocardiographic studies. However, nuclear techniques, showing preserved tracer uptake and metabolism in viable myocardium, may also assess left ventricular function and wall motion. Analysis by gated SPECT imaging offers considerable additional value to SPECT myocardial perfusion imaging in characterizing functional abnormalities thereby potentially improving test specificity [24-30]. Preserved wall motion and/or thickening in region with perfusion defects might denote remaining viability indicating potentially well functioning myocardium [31-36]. By assessing left ventricular

Editorial comment to the article Sipola et al. (doi: 10.1007/s10554-010-9702-4)

E. E. van derWall ( $\square)$. A. J. H. A. Scholte

H. M. Siebelink · J. J. Bax

Department of Cardiology, Leiden University Medical

Center, P.O. Box 9600, Leiden, Netherlands

e-mail: e.e.van_der_wall@lumc.nl volumes the application of gated SPECT influences the appropriate management strategy. Since myocardial perfusion, function and wall motion/thickening can be assessed simultaneously, gated SPECT imaging follows the concept of a one-stop shop such as propagated by MRI studies [37-41]. However, MRI may be more accurate than gated SPECT in establishing left ventricular parameters because of its superb spatial resolution [20, 42-49].

In the current issue of the International Journal of Cardiovascular Imaging, Sipola et al. [50] prospectively compared left ventricular end-diastolic volume (EDV), end-systolic volume (ESV), and ejection fraction (LVEF) both by gated SPECT and cardiac MRI in 21 patients with idiopathic dilated cardiomyopathy. All 21 patients underwent both $99 \mathrm{mTc}-$ tetrofosmin gated SPECT imaging and MRI within a $3 \mathrm{~h}$ interval. Close linear correlations were observed between both methods in left ventricular EDV and left ventricular ESV but correlations were significantly weaker for LVEF. Left ventricular EDV and left ventricular ESV were smaller for gated SPECT than for MRI. In 4 patients $(21 \%)$ the left ventricular EDV index was considered normal by gated SPECT and increased by MRI, if MRI-derived normal values were used. No differences were found between gated SPECT and MRI when MRI-determined LVEF was below $40 \%$. However, gated SPECT showed smaller LVEF when MRI-determined LVEF was over $40 \%$. The authors concluded that an increased left ventricular EDV in gated SPECT is reliable compared with 
MRI. Nevertheless, left ventricular volumes were systematically underestimated by gated SPECT and underestimation was higher in patients with dilated left ventricles. No direct comparisons could be made between the two methods in follow-up studies. Based on these findings [50], the authors suggest that abnormal gated SPECT results should be confirmed by other imaging modalities, such as MRI, if these findings have therapeutic consequences.

In comparing gated SPECT data with data from established imaging techniques, inconsistent results have been reported. Atsma et al. [51] compared technetium-99 m tetrofosmin gated SPECT imaging and contrast ventriculography in the assessment of global and regional left ventricular function in 74 patients with undiagnosed chest pain of whom 27 sustained a previous myocardial infarction. The authors reported that gated SPECT imaging is an accurate and reliable clinical tool to accurately measure global and regional left ventricular function. Bavelaar-Croon et al. [52] compared results from quantitative gated SPECT with results from MRI in the assessment of left ventricular EDV, ESV, and LVEF. Between the two methods, correlations were good for LVEF $(r=0.85)$, EDV $(r=0.94)$, ESV $(r=0.95)$. Wahba et al. [53] showed that gated SPECT imaging when compared to MRI is a reliable tool for the assessment of regional wall motion and thickening in patients with known or suspected coronary artery disease. In particular in patients with a previously sustained myocardial infarction gated SPECT imaging has the potential to detect preserved wall motion and thickening in regions with fixed perfusion defects indicating the potential presence of residual myocardial viability. Bax et al. [54] showed close and significant correlations for assessment of left ventricular volumes, and regional wall motion by MRI and gated SPECT in patients with ischemic cardiomyopathy.

On the other hand, in a meta-analysis including nine studies, Ioannidis and coworkers [55] demonstrated that gated SPECT measurements of left ventricular EDV, ESV and LVEF showed indeed high correlation with cardiac MRI measurements, but substantial errors may occur in individual patients. Persson et al. [56] reported in 55 patients with known or suspected coronary artery disease that gated SPECT, compared with MRI, systematically underestimated EDV, ESV and LVEF. This phenomenon might be due to the inclusion of the outflow tract area by MRI, which is not part of left ventricular volume acquisition with gated SPECT because of low counts in this area. This holds in particular for dilated left ventricles as the basal left ventricle constitutes a higher absolute volume than in patients without left ventricular dilatation. As already noticed by Sipola et al. [50] the study by Wang et al. [57] showed that the correlation between gated SPECT and cardiac MRI was excellent for LV volume and LVEF values in patients with idiopathic dilated cardiomyopathy. However, algorithm-varying over- or underestimation of left ventricular volumes and LVEF should be accounted for in the clinical context.

To summarize, the current study by Sipola et al. [50] clearly demonstrates that gated SPECT offers useful and reliable functional information on left ventricular function, which makes it suitable for follow-up studies and guiding clinical management. However, when accurate measurements of cardiac volumes are required cardiac MRI should be used. This holds in particular for patients with dilated cardiomyopathy.

Open Access This article is distributed under the terms of the Creative Commons Attribution Noncommercial License which permits any noncommercial use, distribution, and reproduction in any medium, provided the original author(s) and source are credited.

\section{References}

1. Bax JJ, van der Wall EE, Harbinson M (2004) Radionuclide techniques for the assessment of myocardial viability and hibernation. Heart 90(5):v26-v33

2. Bavelaar-Croon CD, Pauwels EK, van der Wall EE (2001) Gated single-photon emission computed tomographic myocardial imaging: a new tool in clinical cardiology. Am Heart J 14:383-390

3. van der Wall EE, Heidendal GA, den Hollander W, Westera G, Roos JP (1980) I-123 labeled hexadecenoic acid in comparison with Thallium-201 for myocardial imaging in coronary heart disease. A preliminary study. Eur J Nucl Med 5:401-405

4. Slart RH, Bax JJ, Sluiter WJ, van Veldhuisen DJ, Jager PL (2004) Added value of attenuation-corrected Tc-99m tetrofosmin SPECT for the detection of myocardial viability: comparison with FDG SPECT. J Nucl Cardiol 11:689-696

5. Ten Cate FJ (2009) Cardiomyopathies: a revolution in molecular medicine and cardiac imaging. Neth Heart J 17:456-457

6. America YG, Bax JJ, Dibbets-Schneider P, Pauwels EK, Van der Wall EE (2005) Evaluation of the quantitative 
gated SPECT (QGS) software program in the presence of large perfusion defects. Int $\mathrm{J}$ Cardiovasc Imaging 21: 519-529

7. van Eck-Smit BL, van der Wall EE, Kuijper AF, Zwinderman AH, Pauwels EK (1993) Immediate thallium-201 reinjection following stress imaging: a time-saving approach for detection of myocardial viability. J Nucl Med 34:737-743

8. Groutars RG, Verzijlbergen JF, Tiel-van Buul MM et al (2003) The accuracy of 1-day dual-isotope myocardial SPECT in a population with high prevalence of coronary artery disease. Int J Cardiovasc Imaging 19:229-238

9. van der Wall EE, den Hollander W, Heidendal GA, Westera G, Majid PA, Roos JP (1981) Dynamic myocardial scintigraphy with $123 \mathrm{I}$-labeled free fatty acids in patients with myocardial infarction. Eur J Nucl Med 6:383-389

10. Braun S, van der Wall EE, Emanuelsson S, Kobrin I (1996) Effects of a new calcium antagonist, mibefradil (Ro 40-5967), on silent ischemia in patients with stable chronic angina pectoris: a multicenter placebo-controlled study. The mibefradil international study group. J Am Coll Cardiol 27:317-322

11. Portegies MC, Schmitt R, Kraaij CJ et al (1991) Lack of negative inotropic effects of the new calcium antagonist Ro 40-5967 in patients with stable angina pectoris. J Cardiovasc Pharmacol 18:746-751

12. de Nooijer R, Verkleij CJ, von der Thüsen JH et al (2006) Lesional overexpression of matrix metalloproteinase-9 promotes intraplaque hemorrhage in advanced lesions but not at earlier stages of atherogenesis. Arterioscler Thromb Vasc Biol 26:340-346

13. Hoogendoorn LI, Pattynama PM, Buis B, van der Geest RJ, van der Wall EE, de Roos A (1995) Noninvasive evaluation of aortocoronary bypass grafts with magnetic resonance flow mapping. Am J Cardiol 75:845-848

14. van der Laarse A, Kerkhof PL, Vermeer F et al (1988) Relation between infarct size and left ventricular performance assessed in patients with first acute myocardial infarction randomized to intracoronary thrombolytic therapy or to conventional treatment. Am J Cardiol 61:1-7

15. Bakx AL, van der Wall EE, Braun S, Emanuelsson H, Bruschke AV, Kobrin I (1995) Effects of the new calcium antagonist mibefradil (Ro 40-5967) on exercise duration in patients with chronic stable angina pectoris: a multicenter, placebo-controlled study. Ro 40-5967 International Study Group. Am Heart J 130:748-757

16. van Rugge FP, Boreel JJ, van der Wall EE et al (1991) Cardiac first-pass and myocardial perfusion in normal subjects assessed by sub-second Gd-DTPA enhanced MR imaging. J Comput Assist Tomogr 15:959-965

17. Nijveldt R, Beek AM, Hirsch A et al (2008) 'No-reflow' after acute myocardial infarction: direct visualisation of microvascular obstruction by gadolinium-enhanced CMR. Neth Heart J 16:179-181

18. Bax JJ, Visser FC, van Lingen A, Cornel JH, Fioretti PM, van der Wall EE (1997) Metabolic imaging using F18fluorodeoxyglucose to assess myocardial viability. Int $\mathrm{J}$ Card Imaging 13:145-155

19. Underwood SR, Bax JJ, vom Dahl J et al (2004) Study group of the European society of cardiology. Imaging techniques for the assessment of myocardial hibernation.
Report of a study group of the European society of cardiology. Eur Heart J 25:815-836

20. Torn M, Bollen WL, van der Meer FJ, van der Wall EE, Rosendaal FR (2005) Risks of oral anticoagulant therapy with increasing age. Arch Intern Med 165:1527-1532

21. Slart RH, Bax JJ, van Veldhuisen DJ, van der Wall EE, Dierckx RA, Jager PL (2006) Imaging techniques in nuclear cardiology for the assessment of myocardial viability. Int J Cardiovasc Imaging 22:63-80

22. Slart RH, Bax JJ, van Veldhuisen DJ et al (2006) Prediction of functional recovery after revascularization in patients with chronic ischaemic left ventricular dysfunction: head-to-head comparison between $99 \mathrm{mTc}$-sestamibi/ 18F-FDG DISA SPECT and $13 \mathrm{~N}$-ammonia/ 18F-FDG PET. Eur J Nucl Med Mol Imaging 33:716-723

23. Bleeker GB, Holman ER, Steendijk P et al (2006) Cardiac resynchronization therapy in patients with a narrow QRS complex. J Am Coll Cardiol 48:2243-2250

24. Ypenburg C, van der Wall EE, Schalij MJ, Bax JJ (2008) Imaging in cardiac resynchronisation therapy. Neth Heart $\mathrm{J}$ 16:S36-S40

25. Ypenburg C, Westenberg JJ, Bleeker GB et al (2008) Noninvasive imaging in cardiac resynchronization therapy-part 1: selection of patients. Pacing Clin Electrophysiol 31:1475-1499

26. van der Geest RJ, Niezen RA, van der Wall EE, de Roos A, Reiber JH (1998) Automated measurement of volume flow in the ascending aorta using MR velocity maps: evaluation of inter- and intraobserver variability in healthy volunteers. J Comput Assist Tomogr 22:904-911

27. Tops LF, Schalij MJ, Holman ER, van Erven L, van der Wall EE, Bax JJ (2006) Right ventricular pacing can induce ventricular dyssynchrony in patients with atrial fibrillation after atrioventricular node ablation. J Am Coll Cardiol 48:1642-1648

28. Oemrawsingh PV, Mintz GS, Schalij MJ, Zwinderman AH, Jukema JW, van der Wall EE (2003) Intravascular ultrasound guidance improves angiographic and clinical outcome of stent implantation for long coronary artery stenoses: final results of a randomized comparison with angiographic guidance (TULIP Study). Circulation 107: 62-67

29. Bleeker GB, Bax JJ, Fung JW et al (2006) Clinical versus echocardiographic parameters to assess response to cardiac resynchronization therapy. Am J Cardiol 97:260-263

30. Bleeker GB, Schalij MJ, Boersma E et al (2007) Relative merits of M-mode echocardiography and tissue Doppler imaging for prediction of response to cardiac resynchronization therapy in patients with heart failure secondary to ischemic or idiopathic dilated cardiomyopathy. Am J Cardiol 99:68-74

31. Ypenburg C, Roes SD, Bleeker GB et al (2007) Effect of total scar burden on contrast-enhanced magnetic resonance imaging on response to cardiac resynchronization therapy. Am J Cardiol 99:657-660

32. Ypenburg C, Schalij MJ, Bleeker GB et al (2006) Extent of viability to predict response to cardiac resynchronization therapy in ischemic heart failure patients. J Nucl Med 47:1565-1570

33. Tops LF, Bax JJ, Zeppenfeld K et al (2005) Fusion of multislice computed tomography imaging with three- 
dimensional electroanatomic mapping to guide radiofrequency catheter ablation procedures. Heart Rhythm 2:1076-1081

34. Ypenburg C, Schalij MJ, Bleeker GB et al (2007) Impact of viability and scar tissue on response to cardiac resynchronization therapy in ischaemic heart failure patients. Eur Heart J 28:33-41

35. Ypenburg C, Sieders A, Bleeker GB et al (2007) Myocardial contractile reserve predicts improvement in left ventricular function after cardiac resynchronization therapy. Am Heart J 154:1160-1165

36. Molhoek SG, Bax JJ, van Erven L et al (2004) Comparison of benefits from cardiac resynchronization therapy in patients with ischemic cardiomyopathy versus idiopathic dilated cardiomyopathy. Am J Cardiol 93:860-863

37. Tio RA, Slart RH, de Boer RA et al (2009) Reduced regional myocardial perfusion reserve is associated with impaired contractile performance in idiopathic dilated cardiomyopathy. Neth Heart J 17:470-474

38. van der Wall EE, van Dijkman PR, de Roos A et al (1990) Diagnostic significance of gadolinium-DTPA (diethylenetriamine penta-acetic acid) enhanced magnetic resonance imaging in thrombolytic treatment for acute myocardial infarction: its potential in assessing reperfusion. Br Heart $\mathrm{J}$ 63:12-17

39. Holman ER, van Jonbergen HP, van Dijkman PR, van der Laarse A, de Roos A, van der Wall EE. Comparison of magnetic resonance imaging studies with enzymatic indexes of myocardial necrosis for quantification of myocardial infarct size. Am J Cardiol 71:1036-1040

40. van Rugge FP, Holman ER, van der Wall EE, de Roos A, van der Laarse A, Bruschke AV (1993) Quantitation of global and regional left ventricular function by cine magnetic resonance imaging during dobutamine stress in normal human subjects. Eur Heart J 14:456-463

41. Sciagrà R, Leoncini M (2005) Gated single-photon emission computed tomography. The present-day "one-stopshop" for cardiac imaging. Q J Nucl Med Mol Imaging 49:19-29

42. Pluim BM, Lamb HJ, Kayser HW, Leujes F et al (1998) Functional and metabolic evaluation of the athlete's heart by magnetic resonance imaging and dobutamine stress magnetic resonance spectroscopy. Circulation 97:666-672

43. Pluim BM, Beyerbacht HP, Chin JC et al (1997) Comparison of echocardiography with magnetic resonance imaging in the assessment of the athlete's heart. Eur Heart J 18:1505-1513

44. Pluim BM, Chin JC, De Roos A et al (1996) Cardiac anatomy, function and metabolism in elite cyclists assessed by magnetic resonance imaging and spectroscopy. Eur Heart J 17:1271-1278

45. Kurvers MJ, Braam RL, Verzijlbergen JF, Heestermans AA, Ten Berg JM (2007) Myocardial salvage in STEMI patients treated with primary coronary angioplasty as demonstrated by myocardial SPECT. Neth Heart J $15: 422-423$
46. Germans T, Nijveldt R, Brouwer WP et al (2010) The role of cardiac magnetic resonance imaging in differentiating the underlying causes of left ventricular hypertrophy. Neth Heart J 18:135-143

47. van Dijkman PR, van der Wall EE, de Roos A et al (1991) Acute, subacute, and chronic myocardial infarction: quantitative analysis of gadolinium-enhanced MR images. Radiology 180:147-151

48. van der Wall EE, Vliegen HW, de Roos A, Bruschke AV (1995) Magnetic resonance imaging in coronary artery disease. Circulation 92:2723-2739

49. Vliegen HW, Doornbos J, de Roos A, Jukema JW, Bekedam MA, van der Wall EE (1997) Value of fast gradient echo magnetic resonance angiography as an adjunct to coronary arteriography in detecting and confirming the course of clinically significant coronary artery anomalies. Am J Cardiol 79:773-776

50. Sipola P, Peuhkurinen K, Vanninen E Comparison of photon emission computed tomography with magnetic resonance imaging for evaluation of left ventricular volumes ane ejection fraction in patienst with idiopathic dilated cardiomyopathy. Int $\mathbf{J}$ Cardiovasc Imaging [Epub ahead of print]

51. Atsma DE, Bavelaar-Croon CD, Germano G et al (2000) Good correlation between gated single photon emission computed myocardial tomography and contrast ventriculography in the assessment of global and regional left ventricular function. Int J Card Imaging 16:447-453

52. Bavelaar-Croon CD, Kayser HW, van der Wall EE et al (2000) Left ventricular function: correlation of quantitative gated SPECT and MR imaging over a wide range of values. Radiology 217:572-575

53. Wahba FF, Lamb HJ, Bax JJ et al (2001) Assessment of regional myocardial wall motion and thickening by gated 99Tcm-tetrofosmin SPECT: a comparison with magnetic resonance imaging. Nucl Med Commun 22:663-671

54. Bax JJ, Lamb H, Dibbets P, Pelikan H et al (2000) Comparison of gated single-photon emission computed tomography with magnetic resonance imaging for evaluation of left ventricular function in ischemic cardiomyopathy. Am J Cardiol 86:1299-1305

55. Persson E, Carlsson M, Palmer J, Pahlm O, Arheden H (2005) Evaluation of left ventricular volumes and ejection fraction by automated gated myocardial SPECT versus cardiovascular magnetic resonance. Clin Physiol Funct Imaging 25:135-141

56. Ioannidis JP, Trikalinos TA, Danias PG (2002) Electrocardiogram-gated single-photon emission computed tomography versus cardiac magnetic resonance imaging for the assessment of left ventricular volumes and ejection fraction: a meta-analysis. J Am Coll Cardiol 39:2059-2068

57. Wang F, Zhang J, Fang W, Zhao SH, Lu MJ, He ZX (2009) Evaluation of left ventricular volumes and ejection fraction by gated SPECT and cardiac MRI in patients with dilated cardiomyopathy. Eur J Nucl Med Mol Imaging 36: 1611-1621 